\title{
Effect of Financial Management Practices On Profitability Of Matatu Transport Industry In Kenya
}

\author{
Joseph Kimani Mwangi ${ }^{1}$, Dr Robert Otuya ${ }^{2}$, David K. Kamau ${ }^{3}$ \\ ${ }^{I}$ (Business Department, Nyandarua Institute Of Science And Technology, Kenya) \\ ${ }^{2}$ (Business Department, University Of Eldoret, Kenya) \\ ${ }^{3}$ (Business Department, Jomo Kenyatta University of Agriculture \&Technology, Kenya)
}

\begin{abstract}
Financial Management Practices Are Vital In Any Investment Opportunity. The Effect Of Financial Management Practices On The Profitability Of Organizations Has Not Been Clearly Understood. This Study Aimed At Assessing The Effect Of Financial Management Practices With Respect To Capital Structure And Cost Of Capital On Profitability And Find Out The Extent Of Its Utilization In The Matatu Industry. The Significance Of The Study Was To Create Awareness To Investors And Help Them In Financial Management Practices, Add To The Existing Knowledge And Help The Government In Policy Formulation. The Survey Research Design Was Employed Where The Respondents Were Selected Through A Stratified Random Sampling. Data Was Analyzed Using Descriptive Statistics, Correlation, Factor Analysis And Regression. Equity Capital Was Preferred While Debt Financing Was Used On A Smaller Scale. The Decision To Use Debt Is Largely Influenced By Its Cost And The Attendant Risk, That Is, The Potential Of Not Covering The Debt From The Cash Flows From Operations. Cost Of Capital And Capital Structure Attributed To 94.1\% Of Changes In Profitability In Matatu Industry. The Study Recommends That Matatu Transport Industry Should Seek New Ways For Members To Access Loans At Lower Rates By Entering Into Funding Commitments With The Financial Institutions. Therefore Mechanisms Should Be Put In Place To Ensure Good Financial Management Practices.
\end{abstract}

Key Words: Financial Management Practices (Cost Of Capital And Capital Structure), Matatu, Equity Capital, Debt Capital And Profitability.

\section{Introduction}

There Are A Number Of Investment Opportunities In The World And Investor Should Take Advantage. Investment In Matatu Industry Is An Opportunity That Involves Buying Of Assets Which Require Investing Huge Capital And It Therefore Calls For Financial Management Practices. The Investors' Consideration On The Expected Cost Of Financial Distress Which Depends On The Probability Of Profits And Cost Of Distress Is Imminent. Stable Sales And Lower Operating Leverage Provide Tax Benefits And Reduce The Probability Of Financial Distress (Brigham And Ehrhardt, 2008). Many Studies Focus On Relationship Of Capital Structure And Cost Of Capital On Their Empirical Relationships As Well As On Agency Decisions But, Little Has Been Studied On The Effect Of These Variables On The Profitability Of The Public Service Vehicle (PSV) Transport Industry In Kenya. Hence The Study Is Aimed At Assessing The Effect Of Cost Of Capital And Capital Structure On The Profitability Of Matatu Industry In Kenya

Public Transport In Kenya And Especially In Urban Areas Is Dominated By Matatu Vehicles. Currently, A Matatu Is Described As A 14-Seater Nissan Andtoyota Shark Models Normally Used In Several Routes In The Country. The Name Also Refers To 25-Seater Mini-Bus Which Is Also Called "Manyanga", A Kenyan Slang For "A Very Beautiful Girl”.Matatu Is Also Used To Refer To The Smaller 7-Seater Cars Like The Toyota Municipality Race Model Which Are Preferred For The Upcountry Journey (Aduwo, 1990). In The Early 1960s, The Total Number Of Matatus Operating In The Country Was Less Than 400 And They Operated In Form Of Taxis. In 1973, President Jomo Kenyatta, Responding To Lobbying From Matatu Operators, Declared Matatus A Legal Mode Of Transport That Ferried Fast Paying Passengers Without Obtaining Special Transport Licenses But Had To Comply With Existing PSV Insurance And Other Traffic Regulations (Aduwo, 1994). Kenya Is Integrated Within The International, National And Regional Transportation System. The Country Is Also Connected To Its Hinterland Through National Roads And Is Responsible For A Grid Pattern Roads Throughout The Country. The Country Has Several Means Of Public Transport Like Matatus, Minibuses, Buses, Taxis, Motorbikes, Tuk Tuks (Motorized 3-Wheeled Light Vehicle) And Bicycle Taxis.( PSV Licensing Board Records ,2013)

Financial Management Is A Managerial Activity Which Is Concerned With Planning And Controlling Of The Firms Resources. Though It Was A Branch Of Economics Until 1890, As A Separate Discipline It Draws Heavily On Economics For Its Theoretical Concepts (Pandey, 1999). Financial Management Concerns The Acquisition, Financing And Management Of Assets. The Functions Of Financial Management Can Be 
Broken Down Into Three Major Areas; Investment, Financing And Assets Management Decisions (Horne And Wachowicz, 2001). Efficient Financial Management Requires The Existence Of Some Objectives. An Efficient Financial Decision Made Requires To Have Some Standards. There Are Various Objectives Of Organization And The Major One Being To Maximize The Investors Profitability For Most Firms (Horne And Wachowicz, 2001). Financial Decisions Of The Investors Are Interrelated And Jointly Affect The Market Value Of Its Shares By Influencing Profitability And Risk Of The Organization. A Balance Between Profitability And Risk Require Be Maintained Inorder To Maximize The Market Value Of The Investor. Such A Balance Is Called Risk- Profitability Trade-Off And Every Financial Decision Involves This Trade-Off.

The Financial Manager, In A Bid To Maximize Owners Wealth, Should Strive To Maximize Profitability In Relation To The Given Risk. He Should Avoid Unnecessary Risks, Ensure Maximum Profitability And Net Cash Flow Of The Organization Should Be Constantly Monitored To Assure Investors Investments (Pandey, 1999).

Capital Budgeting Involves The Decision In Allocation Of Capital To Long-Term Assets That Could Yield Benefits In The Future. Two Important Aspects Of Investment Are The Evaluation Of The Prospective Profitability Of New Investment And Comparison Of The Measurement Of A Cut-Off Against The Prospective Return Of New Investments. Future Benefits Of Investments Are Difficult To Measure And Cannot Be Predicted With Certainty. Due To Uncertainty, Future Investment Decisions Involve Risk And Therefore It Is Evaluated In Terms Of Expected Return And Risk (Pandey, 2001). There Is A Broad Agreement That The Correct Cut-Off Rate Is The Required Rate Of Return Or The Opportunity Cost Of Capital.

The Central Issue In Financing Is To Determine The Proportionality Of Equity And Debt Which Is Called Capital Structure. The Investor Must Strive To Obtain The Best Financing Mix Or The Optimum Capital Structure For The Firm. The Firm's Capital Structure Is Considered To Be Optimum When The Market Value Of Shares Is Maximized. The Use Of Debt Affects The Return And Risk Of Shareholder. It May Increase The Return On Equity Capital But It Also Increases Risk. A Proper Balance Will Have To Be Struck Between Return And Risk. When The Shareholder Return Is Maximized With Minimum Risk, The Market Value Per Share Will Be Maximized And The Firm's Capital Structure Would Be Considered Optimum (Pandey, 2001). Once The Financial Manager Is Able To Determine The Best Combination Of Debt And Equity, Then One Must Raise The Appropriate Amount Through The Best Available Sources. In Practice, A Investor Considers Many Other Factors Such As Control, Flexibility, Loan Covenants And Legal Aspects In Deciding Its Capital Structure.

\section{Research Hypotheses 1} Kenya.

Ho: Cost Of Capital Has No Significant Effect On PSV Matatus Transport Industry Profitability In

\section{Research Hypotheses II}

Ho: Capital Structure Has No Significant Effect On PSV Matatus Transport Industry Profitability In Kenya.

\subsection{Capital Structure}

\section{Literature Review}

The Assets Of A Company Or An Investor Can Be Financed Either By Increasing The Owner's Claims. The Owners' Claims Increase When The Firm Raises Funds By Issuing Ordinary Shares Or By Retaining The Earnings; The Creditors' Claims Increase By Borrowing. The Various Means Of Financing Represent The Financial Structure Of A Firm. Traditionally, Short-Term Borrowings Are Excluded From The Lists Of Methods Of Financing The Firm's Capital Expenditure And Therefore, The Long Term Claims Are Said To Form The Capital Structure (Emery, Finnerty And Stowe, 2007). The Capital Structure Decision Was First Tackled In A Vigorous Theoretical Analysis By The Financial Economists Modigliani And Miller In 1958. They Created A Simplified Model Of The World By Making Some Assumptions. Given Those Assumptions They Concluded That The Value Of A Firm Remain Constant Regardless Of The Debt Level. In The Real World Companies Do Not Generally Raise Their Debt-To-Equity Ratio To Very High Levels (Glen, 2008). The Financing Or Capital Structure Decision Is A Significant Managerial Decision, It Influences The Shareholders Return And Risk, Consequently, The Market Value Of The Share May Be Affected By The Capital Structure Decision. The Investor Will Have To Plan Its Capital Structure Firm Initially At The Time Of Its Promotion. Subsequently, Whenever Funds Have To Be Raised To Finance Investments A Capital Structure Decision Is Involved (Brigham And Ehrhardt, 2008). Pandey (1999) Came Up With The Process Of The Capital Structure Decision. 
Figure 2.1 The Capital Structure Decision

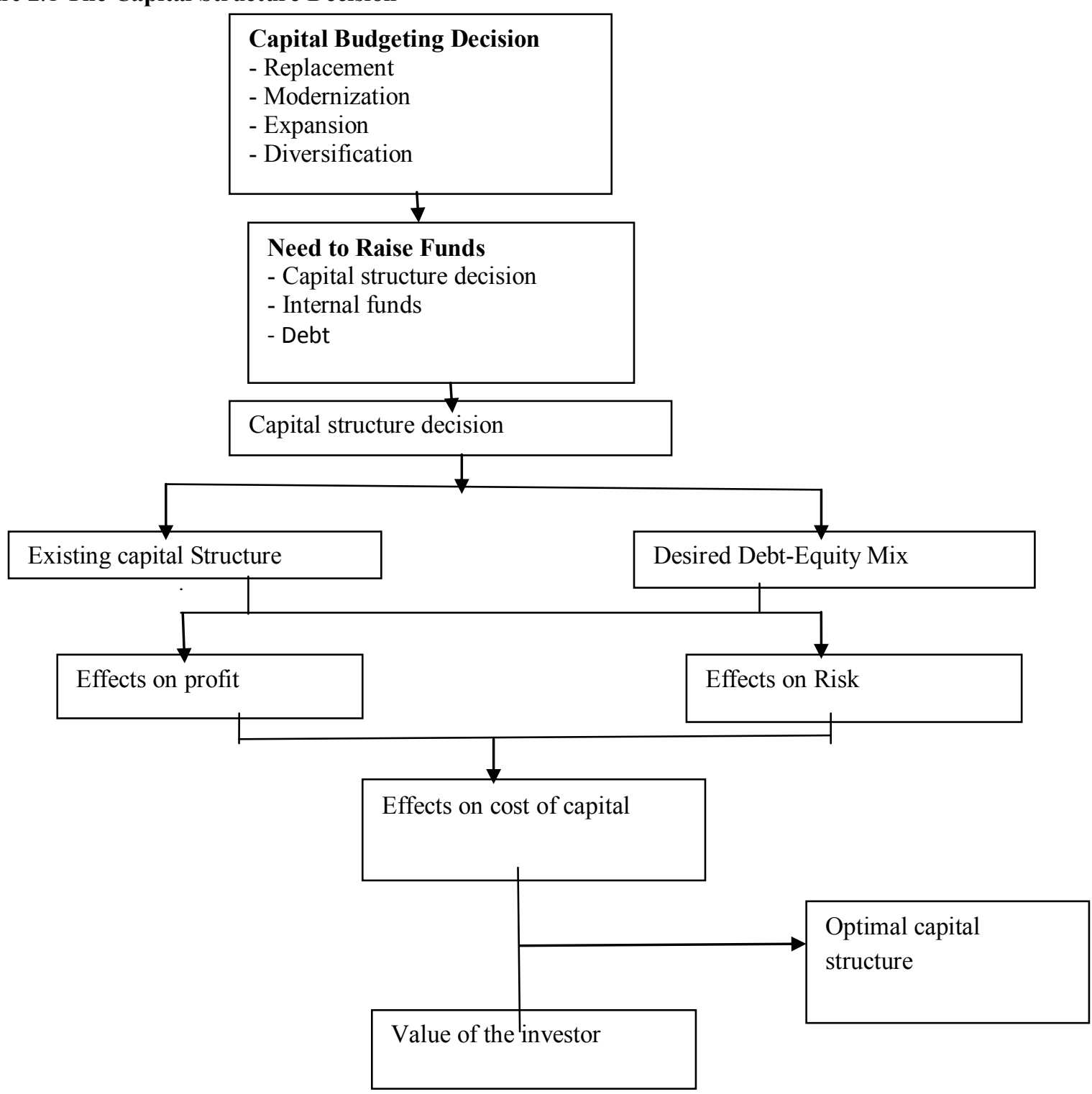

The Demand For Raising Funds Generates A New Capital Structure Since A Decision Has To Be Made As To The Quantity And Forms Of Financing. This Decision Will Involve An Analysis Of The Existing Capital Structure And The Factors Which Will Govern The Decision At The Present. The New Financing Decision Of The Firm May Affect Its Debt-Equity Mix. The Debt-Equity Mix Has Implications For The Shareholders' Earnings And Risk Which In Turn Will Affect The Cost Of Capital And The Value Of The Investor.

According To Brigham And Ehrhardt (2008) Managers Should Choose The Capital Structure That Maximizes Shareholders Wealth. The Basic Approach Is To Consider A Trial Capital Structure Based On The Market Values Of The Debt And Equity, And Then Estimate The Wealth Of The Shareholders Under This Capital Structure. The Approach Is Repeated Until An Optimal Capital Structure Is Identified. There Are Five Steps For The Analysis Of Each Potential Capital Structure:

I) Estimate The Interest Rate The Firm Will Pay.

Ii) Estimate The Cost Of Equity.

Iii) Estimate The Weighted Average Cost Of Capital.

Iv) Estimate The Free Cash Flows And Their Present Values; Which Is The Value Of The Firm.

V) Deduct The Value Of The Debt To Find The Shareholders Wealth Which We Want To Maximize.

Brigham And Daves (2004) Argues That The Business Risk And Tax Position Need Financial Flexibility, Managerial Conservatism Or Aggressiveness And Growth Opportunities Influence The Firm's Capital Structure. Pandey (2001) Argues That The Value Of The Firm Or The Investor Depends Upon Its Expected Return And The Rate Used To Discount The Expected Return. Thus, The Capital Structure Decision Can Affect 
The Value Of The Investor By Changing The Expected Profit Or The Cost Of Capital Or Both. Leverage Cannot Change The Total Expected Return Of The Investor, But It Can Affect The Residue Return Of The Shareholders. The Effect Of Leverage On The Cost Of Capital Is Not Very Clear Conflicting Opinions Have Been Expressed On This Issue. In Fact, This Issue Is One Of The Most Contentious Areas In The Theory Of Finance And Perhaps More Theoretical And Empirical Work Has Been Done On The Subject Than On Any Other. If Leverage Affects The Cost Of Capital And The Value Of 9 The Firm, An Optimum Capital Structure Would Be Obtained At The Combinations Of Debt And Equity That Maximize The Total Value Of The Investor. Given That A Firm Has A Certain Structure Of Assets Which Offers Net Operating Earnings Of A Given Size And Quality And Given A Certain Structure Of Rates In The Capital Markets Is There Some Specific Degree Of Financial Leverage In Which The Market Value Of The Firm's Securities Will Be Higher (Or The Cost Of Capital Will Be Lower) Than At Other Degrees Of Leverage (Brigham And Deves, 2004).

The Existence Of An Optimum Capital Structure Is Not Accepted By All. There Exist Two Extreme Views And A Middle Position. David Durand Identified The Two Extreme Views The Net Income And Net Operating Approaches. The Net Income Approach; The Cost Of Debt And Cost Of Equity Are Assumed To Be Independent To Form Capital Structure, The Weighted Average Cost Of Capital Declines And The Total Value Of The Firm Rises With Increase Use Of Leverage. The Net Operating Income (NOI) Approach, The Cost Of Equity Is Assumed To Increase Linearly With Leverage. As A Result, The Weighted Average Cost Of Capital Remains Constant And The Total Value Of The Firms Also Remain Constant As Leverage Is Changed. Brigham And Ehrhardt (2008) Support The NOI Approach By Providing Logically Consistent Behavioral Justification In Its Favour. They Deny The Existence Of The Optimum Capital Structure. According To (Horne And Wachowicz, 2001) For One To Understand The Capital Structure And Face Value Of The Firm One Has To Make Assumptions Which Are Firms Employ Only Two Type Of Capital: Debt And Equity, The Total Assets Of The Firm Are Given, Investors Have The Same Subjective Probability Distribution Of Expected Return, The Firm Has A Policy Of Pay 100 Per Cent Dividends; Business Risk Is Assumed To Be Constant And Independent Of Capital Structure, Finally The Corporate And Personal Income Taxes Do Not Exist.

\subsection{The Cost Of Capital}

Decisions To Develop New Products, Build Factories And Distribution Centers, And Install Information Technology And Acquiring Other Companies Are Some Of The Most Important Business Decisions That Require Capital. In Making These Decisions, A Company Approximate The Total Investment Required And Determine Whether The Expected Rate Of Return Exceeds The Cost Of The Capital. The Cost Of Capital Is Also Used In Many Compensation Plans, With Bonuses Dependent On Whether Company's Return On Invested Capital Exceeds The Cost Of Capital (Ehrhardt, 1994). It Should Be Recognized At The First Outset That The Cost Of Capital Is One Of The Most Difficult And Ten Most Disputed Topics In Finance Theory, Financial Experts Express Conflicting Opinions On The Methods Of Measuring Cost Of Capital. Cost Of Capital Is A Vital Concept In Financial Decision Making. It Is Useful As A Standard For Evaluating Investment Decision, Designing A Firm's Debt Policy And Appraising The Financial Performance Of Top Management. The Cost Of Capital Can Also Be Useful In Deciding About The Methods Of Financing At A Point Of Time (Ehrdardt, 1994). The Investors Cost Of Capital Is The Average Of The Opportunity (Or Required Rates Of Return) Of Various Securities Which Have Claims On The Organization Assets (Pandey, 2001). The Required Rates Of Return Are Market-Determined. The Market Price Of Securities Is A Function Of The Return Expected By The Investors. The Forces Of Demand And Supply Establish Equilibrium Rates For Various Securities. Glen (2008) Gives The Formula Of Cost Of Capital.

$$
\mathrm{I}_{0}=\mathrm{CF}_{1} / 1+\mathrm{K}+\mathrm{CF}_{2} /(1+\mathrm{K})^{2}+----\mathrm{Cf}_{\mathrm{n}} /(1+\mathrm{K})^{\mathrm{N}} \quad \text { Equation }
$$

Where $\mathrm{I}_{0}$ Is The Capital Supplied By The Investors In Period 0,

CF Are The Return Expected By Investor And

$\mathrm{K}$ Is The Required Cost Of Capital.

The Cost Of Capital Is The Internal Rate Of Return Which Equates The Present Values Of Cash Flow Of A Financial Opportunity. An Organization May Borrow Funds From Financial Institutions Or Public Either In The Form Of Public Deposits Or Debentures For A Specified Period Of Time At A Certain Rate Of Interest. The Contractual Rate Of Interest Forms The Basis For Calculating The Cost Of Any Form Of Debt (Pandey, 2001). Firms May Raise Equity Capital Internally By Retaining Earnings. Alternatively, They Could Distribute The Entire Earnings To Equity Shareholders And Raise Equity Capital Externally By Issuing New Shares. In Both Cases Shareholders Are Providing Capital To The Firms To Finance Their Capital Expenditures. Therefore, The Equity Shareholders' Required Rate Of Return Will Be The Same Whether They Supply Capital By Purchasing New Shares Or By Foregoing Dividends Which Could Have Been Distributed To Them (Taggart, 1991). An Investor Obtains Capital From Various Sources Due To Risk Differences And The Contractual Agreement Between The Financial Institutions And The Investor. The Cost Of Capital Of Each Source Differs From Different Financial Institutions. The Aggregate Cost Of All Sources Of Capital Is Known 
As Overall Or Average Cost Of Capital. In Practice Investors Do Not Use All Sources Of Capital That Are Related To Each Other. The Investor's Decisions To Use Debt In A Given Period Reduce Its Future Debt Capacity As Well As Increases Risk To Shareholders. The Share Holder Will Require A Higher Rate Of Return To Compensate For The Increased Risk. Similarly, The Firm's Decision To Use Equity Capital Will Enlarge Its Potential For Borrowings In The Future. Over The Long Run The Organization Will Maintain A Balance Between Debt And Equity, Because Of The Connection Between The Sources Of Capital And The Organization Desire To Have A Balance Capital Structure In The Long Run. It Is Generally Agreed That The Cost Of Capital Should Be Used In Composite (Pandey, 2001).

\subsection{Portfolio Theory}

The Portfolio Theory Provides A Normative Approach To Investing The Entire Wealth In A Single Asset Or Security. Modern Portfolio Theory (MPT) Proposes How To Make A Decision To Invest In Assets Or Securities Under Risk. It Is Based In The Assumption That Investors Are Risk-Averse (Pandey, 2001). This Implies That Investors Hold Well-Diversified Portfolio Instead Of Investing The Entire Wealth In A Single Asset Or Security. Modern Portfolio Theory Proposes How Rational Investors Will Use Diversification To Optimize Their Portfolio And How A Risky Asset Should Be Priced. Recent Innovations In Theory Particularly Under The Rubric Of Post-Modern Portfolio Theory (PMPT) Have Exposed Several Flaws In This Reliance Of Variance As The Investors Risk Proxy. The Capital Allocation Line (CAL) Is The Line Of The Expected Return Plotted Against Risk (Standard Deviation) That Connects The Entire Portfolio That Can Be Formed Using A Risky Assets And A Riskless Asset. Brigham (2002) Also Proved That It Is A Straight Line And It Has The Following Equation:

In This Formula P Is The Portfolio

$$
\mathrm{CAL}=\mathrm{E}(\mathrm{Rc})=\mathrm{Rf}+\partial \mathrm{CE}(\mathrm{Rp})-\mathrm{Rf} / \partial \mathrm{P} \quad \text { Equation }
$$

F Is The Risk Less Portfolio And

C Is A Combination Of Portfolio P And F.

Mathematically The Efficient Frontier Is The Intersection Of The Set Of Portfolios With Minimum Variance (Mvs) And The Set Of Portfolios With Maximum Return. Formally The Efficient Frontier Is The Set Of Maximal Elements With Respect To The Partial Order Of Product On Risk And Return.

The Capital Asset Pricing Model Specifies The Relationship Between Risk And Required Rates Of Return On Asset In Well-Diversified Portfolios. Brigham (2002) Examines The Assumptions Behind CAPM Which Are: All Investors Focus On A Single Holding Period And They Seek To Maximize The Expected Utility Of Their Terminal Wealth By Choosing Among Alternatives Portfolios On The Basis Of Each Portfolio Expected Return And Standard Deviation, All Investors Can Borrow An Unlimited Amount At A Given Risk-Free Rate And There Are No Restrictions On Short Sales Of Any Assets ( Investors Have Homogenous Expectations), All The Assets Are Perfectly Divisible And Perfectly Liquid, There Are No Transaction Cost And Taxes And Finally The Quantities Of All Assets Are Given And Fixed. Copeland, Shastri And Weston (2005) Suggested The Uses Of CAPM As Determining The Cost Of A Security, Determination Of Weighted Average Cost Of Capital, In Capital Budgeting And Valuation Of Securities. The CAPM Is A Single-Factor Model Which It Specifies Risk As A Function Of Only One Factor, The Security's Beta Coefficient (Brigham And Daves, 2004).Many Factors May Be Required To Specify The Equilibrium Risk/Return Relationship And Thus The Capital Pricing Model Faced A Number Of Challenges. The CAL And CAPM Are Often Contrasted With The Arbitrage Pricing Theory Which Holds That The Expected Return Of A Financial Asset Can Be Modeled To A Linear Function Of Various Macro-Economic Factors, Where Sensitivity To Changes In Each Factor Is Represented By A Factor Specific Beta Coefficient (Brigham And Ehrhardt, 2008).

It Is An Extension Of The Traditional Modern Portfolio Theory Also Called Mean-Variance Analysis. Both Theories Propose How Rational Investors Should Use Diversification To Optimize Their Portfolios And How A Risk Asset Should Be Priced. Markowitz (1959) Laid The Foundation Of MPT The Greatest Contribution Of Which Is The Establishment Of A Formal Risk/Return Framework For Investment Decision Making. It Has Long Been Recognized That Investors Typical Do Not Establish The Returns Above The Minimum They Must Earn In Order To Achieve Their Investment Objectives. They Believe That Risk Has Much To Do With Bad Outcome When Returns Are Below The Required Target. The Good Outcome Is Return In Excess Of The Target And That Losses Weigh More Heavily Than Gains.

\subsection{The Capital Asset Pricing Model, Risk And Return}

The Holy Grail Of Finance Is The Search For The Relationship Between Risk And Required Rates Of Return. The Relationship Affects The Securities Purchased And Sold By Investors And The Strategies Adopted By Portfolio Managers. In Fact Most Decisions In Finance Boil Down To The Trade-Off Between Risk And Return (Brigham And Ehrhardat, 2008). The CAPM Was The First Theory Of Risk And Return To Become Widely Used By Analyst Investors And Corporations. The CAPM Key Contributions Is The Insight That 
Required Return Should Not Be Affected By Diversifiable Risk And That Only None Diversifiable Risk Matters. Indeed Investors Have Become More Diversified As The CAPM Has Become More Widely Known. However, Despite The CAPM's Intuitive Appeal, A Number Of Studies Have Raise Concerns About Its Validity. Fama And French (1992) Cast A Doubt On The CAPM, Found Out That The Two Variables Are Consistently Related To Stock Returns; After Adjusting For Other Factors They Found That Smaller Firms Provided Relatively Higher Returns On Stocks With Lower Markets Ratio. Contrary To The CAPM They Found No Relationship Between Stocks Beta And Its Return. According To Brown (2009), Most Of The Early Evidence Regarding The Relationship Between Rates Of Returns And Systematic Risk Of Portfolios Supported The CAPM. The Literature Provided Extensive Evidence That Size, The Profitability Equity Ratio, Financial Leverage And The Book-To-Market Value Ratio Have Explanatory Power Regarding Returns Beyond Beta. Kothari And Shanken (1997) Measured Beta With Annual Returns To Avoid Trading Problems And Found Substantial Compensation For Beta Risk. They Suggested That The Results Obtained By Fama And French (1992) May Have Been Time Period-Specific And Might Not Be Significant Over A Longer Period. Pettangall, Dundaram And Mathrur (1995) Noted That Empirical Studies Used Realized Returns To Test The CAPM Model When Theory Specifies Expected Returns. When They Adjusted For Negative Market Excess Returns, They Found A Consistent And Significant Relationship Between Beta And Rates Of Return. When Jagannathan And Wang (1996) Employed A Conditional CAPM That Allows For Changes In Betas And In The Market Risk Premium This Model Performed Well In Explaining The Cross Section Of Returns. Grundy And Malkiel (1996) Also Contend That Beta Is A Very Useful Measure Of Risk During Declining Markets Which Is When It Is Most Important. Finally, When Reilly And Wright (2004) Examined The Risk Adjusted Performance For 31 Different Asset Classes Utilizing Betas Computed Using A Very Broad Proxy For The Market Portfolio. The Risk-Return Relationship Was Significant As Expected In CAPM Theory.

\subsection{Summary And Gaps To Be Filled By The Study}

Emery, Finnety And Stowe (2007) Conducted A Study To Investigate Debt-Equity Ratio In The Private Corporate Sector In India, He Tested The Relation Of Debt Equity Ratio With Age, Total Asset, Retained Earnings, Profitability And Capital Intensity. He Found That Age, Retained Earnings And Profitability Were Negatively Correlated While Total Assets And Capital Intensity Was Positively Related To Debt-Equity Ratio. Pandey's (1999) Study About The Corporate Managers Attitude Towards Use Of Borrowing In India Revealed That The Practicing Managers Generally Preferred To Borrow Instead Of Using Other Sources Of Funds Because Of Low Cost Of Debt Due To The Interest Tax Deductibility. Pandey (2001) Conducted Another Empirical Study Examining The Industrial Patterns, Trends And Volatilities Of Leverage And The Impact Of Size, Profitability And Growth On Leverage. Sharpe (2007) Studied The Impact Of Size, Growth, Business Risk, Dividend Policy, Profitability, Debt Service Capacity And The Degree Of Operating Leverage On The Leverage Ratio Of The Firm.

A Number Of Studies Have Been Done Relating To Financing And Agency Decisions But None Has Exploited On The Effect Of Capital Structure And Cost Of Capital On Profitability Of Matatu Industry. Therefore This Study Aimed At Assessing The Effect Of Financial Management Practices With Regard To Capital Structure And Cost Of Capital On Profitability With A Case Of Narokline Service Limited In Narok County.

\section{Research Methodology}

The Study Applied A Survey Research Design Involving The Narokline Service Limited Conducting Matatu Business Which Operates On A Number Of Routes. Survey Is Reliable Due To Its Consistency As There Is Probability Of Producing The Same Results After Repeated Measurements And Gives The Researcher Control Of The Research Environment (Kothari, 2006).

The Target Population Included 78 Matatu Operators Composed Of 30 Shareholders And 48 Non Shareholders (NSL, 2012). The Research Applied Stratified Random Sampling Technique Where The Target Population Was Divided Into Shareholders And Non Shareholders Making A Total Of 2 Strata. Mugenda And Mugenda (2003), A Representative Sample Must Be At Least 10\% Of The Entire Target Population. In This Case, Proportional Allocation According To The Sizes Of The Samples From The Different Strata Were Worked Out As Recommended By Kothari (2006) To Obtain A More Precise Estimate For Each Stratum. The Desirable Sample Size Was 56 Respondents (72\%) Of The Target Population. The Sample Size Was Then Divided By The Sample Size For Each Strata To Achieve A Desired Representation. 
Table1: Sample Size

\begin{tabular}{|l|l|l|}
\hline Distributionrespondents & Frequency & Proportion Allocation \\
\hline Shareholders & 30 & $56(30 / 78)=22$ \\
\hline Non-Shareholders & 48 & $56(48 / 78)=34$ \\
\hline Total & 78 & 55 \\
\hline & & \\
\hline
\end{tabular}

Primary Data Was Collected Through Self Administered Questionnaires With Both Closed And Open-Ended Question To Seek For A Non-Biased Response From The Respondents And Ensure That Results Were Favourable To The Objective Of The Study. The Questionnaire Were Considered The Best In Collection Of Primary Data Because They Provided An Avenue For The Researchers To Ask Probing Questions, They Are Fast, Cheap And Can Be Self-Administered (Mugenda And Mugenda 2003). The Key Variable For Which Data Were Collected Was The Cost Of Capital And Capital Structure In Relation To The Dependent Variable Profitability.

The Researcher Offered Assistance On Matters Such As Interpretation Of Questions That Were Unclear To The Respondents. This Ensured Accuracy And Honesty In Filling Out The Questionnaires By Respondents.

\section{Data Analysis Model}

The Collected Questionnaires Were First Checked For Inconsistencies And Coded. The Data Was Analyzed By use of Descriptive and Inferential Statistics Which Involved Measure Of Central Tendency, Dispersions, Correlation And Regression In Investigating The Effect Of Financial Management Practices On Profitability With Regard To Cost Of Capital And Capital Structure. The Regression Model Was

$$
\mathrm{Y}=\mathrm{B}_{0}+\mathrm{B}_{1} \mathrm{X}_{1}+\mathrm{B}_{2} \mathrm{X}_{2}+\gamma \quad \text { Equation }
$$

Where Y Is The Dependent Variable (Profitability)

$\mathrm{B}_{0}$ Is Constant Profit

$\mathrm{B}_{1}$ Is The Coefficient Of Cost Of Capital

$\mathrm{B}_{2}$ Is The Coefficient Of Capital Structure

$\mathrm{X}_{1}$ Is The Cost Of Capital

$\mathrm{X}_{2}$ Is The Capital Structure

$\gamma$ Is The Random Term

\subsection{Descriptive Analysis}

\section{Results And Discussions}

The Respondents Were Divided Into Shareholders And Non-Shareholders. Since Financial Management Is Based On The Proposition Of Shareholder Wealth Maximization (Pandey, 1999), This Categorization Was Considered Reasonable.

Table2: Designation Of Respondents

\begin{tabular}{|l|l|l|}
\hline Respondents & Frequency & Percentage \\
\hline Shareholder & 21 & 38.2 \\
\hline Non-Shareholder & 34 & 61.8 \\
\hline Total & 55 & 100.0 \\
\hline
\end{tabular}

Table 2 Illustrates That 38.2\% Of The Respondents Were Shareholders While 61.8\% Were Non- Shareholders

Table3: Gender Of Respondents

$\begin{array}{lll}\text { Gender } & \text { Frequency } & \text { Percentage } \\ \text { Male } & 30 & 57.7 \\ \text { Female } & 22 & 42.3 \\ \text { Total } & 52 & 100.0\end{array}$

According To Table 3, 57.7\% Of The Respondents Were Male While 42.3\% Were Female. This Fulfils The Gender Parity Of The Kenyan Constitution.

Table5: Education Level Of Respondents

\begin{tabular}{|c|c|c|c|c|c|c|}
\hline Primary & & & Tertiary & Graduate & Postgraduate & Total \\
\hline Frequency & 1 & 7 & 20 & 23 & 2 & 53 \\
\hline Percentage & 1.9 & 13.2 & 37.7 & 43.4 & 3.8 & 100.0 \\
\hline
\end{tabular}

Most Of The Respondents Were Graduates At 43.4\%, Followed By Tertiary Level Of Education (37.7\%), Secondary Level Of Education Was At 13.2\% While Postgraduate Was At 3.8\% And Primary Level Of Education Was At About 1.9\%. The Significance Of The Respondent's Level Of Education Was That A Relatively Sophisticated Level Of Financial Literacy Was Expected. 
Study Surveyed The Benefits Of Joining An Organized Body Like NSL By Matatu Owners And Operators. The Results Given In Table 6 Shed Light On The Perceptions Of Respondents About The Benefits Of NSL Where Each Benefits Was Rated From Scale 1 To 5 From Not At All Important To Extremely Important.

Table6: Benefits Membership

\begin{tabular}{|c|c|c|c|c|c|c|c|}
\hline Members' Benefits & $\begin{array}{ll}1 . & \text { Not } \\
\text { Important }\end{array}$ & $\begin{array}{l}\text { 2.Less } \\
\text { Importance }\end{array}$ & 3.Neutral & 4. Important & $\begin{array}{l}\text { 5.Very } \\
\text { Important }\end{array}$ & Mean & $\delta$ \\
\hline Branding & $5(9 \%)$ & $3(5.5 \%)$ & $10(18.2 \%)$ & $21(38.2 \%)$ & $16(29.1 \%)$ & 3.73 & 1.189 \\
\hline $\begin{array}{l}\text { Maintence And } \\
\text { Repairs }\end{array}$ & $3(5.5 \%)$ & $4(7.3 \%)$ & $8(14.5 \%)$ & $27(49.1 \%)$ & $13(23.6 \%)$ & 3.78 & 1.06 \\
\hline GPRS Tracking & $10(18.2 \%)$ & $10(18.2 \%)$ & $6(11 \%)$ & $20(36.4 \%)$ & $7(12.7 \%)$ & 2.96 & 1.46 \\
\hline Legal Representation & $14(25.5 \%)$ & $8(14.5 \%)$ & $4(7.3 \%)$ & $23(41.8 \%)$ & $3(5.5 \%)$ & 2.71 & 1.48 \\
\hline Parking & $3(5.5 \%)$ & $5(9 \%)$ & $2(3.6 \%)$ & $27(49.1 \%)$ & $16(29.1 \%)$ & 3.76 & 1.32 \\
\hline $\begin{array}{l}\text { Give Customers Clear } \\
\text { Guidelines }\end{array}$ & $2(3.6 \%)$ & $4(7.3 \%)$ & $1(1.8 \%)$ & $28(50.9 \%$ & $20(36.4 \%)$ & 4.09 & 1.00 \\
\hline Ticketing Systems & $6(11 \%)$ & $5(9 \%)$ & $3(5.5 \%)$ & $25(45.5 \%)$ & $17(30.9 \%)$ & 3.82 & 1.07 \\
\hline
\end{tabular}

In Examining The Benefits Of The Organization, The Results Indicates That Most Of The Respondents

Agreed That They Attach Great Importance To The Benefits And That's Why They Join The Organization Which Shows The Expected Value Of The Aggregate Mean As 3.55 And A Standard Deviation Of 1.23. These Findings Are Consistent With The Findings Of Pandey (2001) Which Indicate That In A Bid To Maximize Owners' Wealth, One Should Strive To Maximize Profit In Relation To The Given Risk And Should Avoid Unnecessary Risks, Ensure Maximum Cash Flow Which Should Be Constantly Monitored To Assure Investors That They Are Safeguarded And Properly Utilized.

Table7: Summary Of Source Of Financing

\begin{tabular}{|c|c|c|c|c|c|c|c|}
\hline & $\begin{array}{l}\text { 1.Strongly } \\
\text { Disagree }\end{array}$ & 2.Disagree & 3.Not Sure & 4.Agree & $\begin{array}{l}\text { 5.Strongly } \\
\text { Agree }\end{array}$ & Mean & $\Delta$ \\
\hline Equity Financing & $4(7.3 \%)$ & $5(9 \%)$ & $10(18.2 \%)$ & $15(27.3 \%)$ & $20(36.4 \%)$ & 3.71 & 1.34 \\
\hline Debt Financing & $25(45.5 \%)$ & $16(29.1 \%)$ & $10(18.2 \%)$ & $2(3.6 \%)$ & $2(3.6 \%)$ & 1.91 & 1.05 \\
\hline Cost Of Debt & $28(50.1 \%)$ & $18(32.7 \%)$ & $8(14.5 \%)$ & $1(1.8 \%)$ & 0 & 1.67 & 0.79 \\
\hline Source Of Finance & $24(43.6 \%)$ & $12(21.8 \%)$ & $4(3.7 \%)$ & $10(18.2 \%)$ & $4(3.7 \%$ & 2.18 & 1.39 \\
\hline Risk Of Capital & $4(3.7 \%)$ & $5(9 \%)$ & $6(10.9 \%)$ & $16(29.1 \%)$ & $24(43.6 \%)$ & 3.93 & 1.24 \\
\hline Security Of Debt & $5(9 \%)$ & $6(10.9 \%)$ & $6(10.9 \%)$ & $24(43.6 \%)$ & $14(25.5 \%)$ & 3.65 & 1.24 \\
\hline Loan Access & $6(10.9 \%)$ & $8(14.5 \%)$ & $12(21.8 \%)$ & $25(45.5 \%)$ & $4(3.7 \%)$ & 3.24 & 1.12 \\
\hline Source Of Capital & $15(27.3 \%)$ & $14(25.5 \%)$ & $2(3.6 \%)$ & $12(21.8 \%)$ & $12(21.8 \%)$ & 2.85 & 1.56 \\
\hline
\end{tabular}

The Research Assessed The Effect Of The Cost Of Capital And Capital Structure On The Profitability In Matatu Industry, The Statements Were Rated From 1 To 5( Strongly Disagree To Strongly Agree). The Respondents, Indicated To What Extent They Agree. Table 7 Illustrates The Findings. When The Respondents Were Asked On The Most Preferred Source Of Capital, Equity Received Higher Rating Than Debt; With A Mean Of 3.71 And Standard Deviation Of 1.34 Compared To A Mean Of 1.91 And Standard Deviation Of 1.05 On Debt. The Respondents Who Preferred Equity Was 43.6\% As Indicated In Table 8 And Those Who Preferred Both Equity And Debt Was 36.4\% In Comparison To Only 12.7\% Of The Respondent Who Preferred Debt Only. Brigham And Ehrhardt (2008) Said That Managers Should Choose The Capital Structure That Maximizes Shareholders Wealth. The Basic Approach Is To Consider A Trial Capital Structure Based On The Market Values Of The Debt And Equity And Then Estimate The Wealth Of The Shareholders Under That Capital Structure. It Is Not Enough To Just Acknowledge The More Preference For Owner Contributed Funds, But Other Factors Need To Be Taken Into Account To Form A More Complete Picture. In This Regard, The Cost Of Debt Or The Interest Rate Is Considered Since It Is The Major Hindrance To The Use Of Debt.

The Determinants Of Source Of Financing At A Mean Of 2.18, Standard Deviation Of 1.39, Risk Of Debt Financing At A Mean Of 3.93 And Standard Deviation Of 1.24 And The Cost Of Debt At A Mean Of 1.67, Standard Deviation Of 0.79 Was Considered To Be An Important Component. Ehrhardt (1994) Argues That Cost Of Debt Is A Key Factor In Choosing The Mixture Of Debt And Equity Used To Finance The Firm And In Making Decisions On Whether To Lease Or Buy Assets. Pandey (2001) Said The Investor's Decisions To Use Debt In A Given Period, Reduces Its Future Debt Capacity As Well As Increasing Risk To Shareholders'. Similarly The Firm's Decision To Use Equity Capital Will Enlarge Its Potential For Borrowing In The Future. The Other Issues That One Considers When Applying For Loan Are The Risks Associated With Debt Such As The Potential For Bankruptcy, Interest Coverage, Security For Loan, Bank Relationship, The Access To Capital Markets, And The Effects Of Financing On The Operational Efficiency Of The Firm. From Table 7 The Research Concludes That While Debt Is Not The Most Preferred Source Of Capital, The Two Factors Security And Access Help Make It Likely To Be Used. 
Table 8: Capital Structure

\begin{tabular}{|l|l|}
\hline & Number Of Respondents \\
\hline Equity & $24(43.6 \%)$ \\
\hline Debt & $7(12.7 \%)$ \\
\hline Debt And Equity & $20(36.4 \%)$ \\
\hline
\end{tabular}

Table 9: Cost Of Capital

\begin{tabular}{|l|l|l|l|l|l|l|l|}
\hline Cost Of Debt & 1. Below 10\% & $2.10 \%-15 \%$ & $3.15 \%-20 \%$ & $4.20 \%-25 \%$ & 5. Above $25 \%$ & Mean & $\Delta$ \\
\hline $\begin{array}{l}\text { Number Of } \\
\text { Respondents }\end{array}$ & $4(7.3 \%)$ & $24(43.6 \%)$ & $12(21.8 \%)$ & $10(18.2 \%)$ & $5(9.1 \%)$ & 2.78 & 1.117 \\
\hline
\end{tabular}

As Illustrated In Table 9, The Cost Of Capital Was Between 10\% And 15\% For Most Of The Respondents In Comparison To Only 7.3\% Whose Cost Of Debt Was Below 10\%. The Cost Of Debt Is A Hindrance To Matatu Transport Industry Investment With 23.3\% Of The Respondents Pay Above 20\% Cost Of Debt.

Table 10: Profitability

\begin{tabular}{|c|c|c|c|c|c|c|c|}
\hline & $\begin{array}{l}\text { Strongly } \\
\text { Disagree } \\
1\end{array}$ & $\begin{array}{l}\text { Disagree } \\
2\end{array}$ & $\begin{array}{l}\text { Not Sure } \\
3\end{array}$ & $\begin{array}{l}\text { Agree } \\
4\end{array}$ & $\begin{array}{l}\text { Strongly } \\
\text { Agree } \\
5\end{array}$ & Mean & $\Delta$ \\
\hline $\begin{array}{l}\text { Money I Receive By Affiliating With The } \\
\text { Organization Is More Than I Would } \\
\text { Generate Elsewhere }\end{array}$ & $\begin{array}{l}4 \\
(7.3 \%)\end{array}$ & $\begin{array}{l}6 \\
(10.9 \%)\end{array}$ & $\begin{array}{l}12 \\
(21.8 \%)\end{array}$ & $\begin{array}{l}18 \\
(32.7 \%)\end{array}$ & $\begin{array}{c}15 \\
(27.3 \%)\end{array}$ & 3.62 & 1.19 \\
\hline $\begin{array}{l}\text { The Organization Provides Investors With } \\
\text { A More Steady Predictable Cash Flows. }\end{array}$ & $\begin{array}{l}8 \\
(14.5 \%) \\
\end{array}$ & $\begin{array}{l}10 \\
(18.2 \%)\end{array}$ & $\begin{array}{l}8 \\
(14.5 \%)\end{array}$ & $\begin{array}{l}20 \\
(36.4 \%)\end{array}$ & $\begin{array}{l}9 \\
(16.4 \%)\end{array}$ & 3.22 & 1.31 \\
\hline $\begin{array}{lll}\text { I Am Very } & \text { Satisfied With The Cash } \\
\text { Generated } & \text { From The Business } \\
\text { Considering The Risks Involved }\end{array}$ & $\begin{array}{l}12 \\
(21.8 \%)\end{array}$ & $\begin{array}{l}10 \\
(18.2 \%)\end{array}$ & $\begin{array}{l}2 \\
(3.6 \%)\end{array}$ & $\begin{array}{l}18 \\
(32.7 \%)\end{array}$ & $\begin{array}{l}13 \\
(23.6 \%)\end{array}$ & 3.18 & 1.46 \\
\hline $\begin{array}{l}\text { Matatu Transport Business Operations } \\
\text { Generate Cash Routinely So That There Is } \\
\text { No Need To Borrow Or Ask For Overdraft } \\
\text { Facilities }\end{array}$ & $\begin{array}{l}4 \\
(7.3 \%)\end{array}$ & $\begin{array}{l}2 \\
(3.6 \%)\end{array}$ & $\begin{array}{l}1 \\
(1.8 \%)\end{array}$ & $\begin{array}{l}24 \\
(43.6 \%)\end{array}$ & $\begin{array}{l}19 \\
(34.5 \%)\end{array}$ & 3.67 & 1.59 \\
\hline $\begin{array}{l}\text { The Operations Of Matatu Transport } \\
\text { Business Are Not Affected By Other } \\
\text { Problems In The Economy Such As } \\
\text { Unemployment, Rising Prices, Etc }\end{array}$ & $\begin{array}{l}26 \\
(47.3 \%)\end{array}$ & $\begin{array}{l}20 \\
(32.7 \%)\end{array}$ & $\begin{array}{l}6 \\
(10.9 \%)\end{array}$ & $\begin{array}{l}3 \\
(5.5 \%)\end{array}$ & 0 & 1.75 & 0.848 \\
\hline $\begin{array}{l}\text { Changes In The Business Environment } \\
\text { Brought About By Government Directives } \\
\text { Affect The Profit From The Business } \\
\text { Favourably }\end{array}$ & $\begin{array}{l}20 \\
(36.4 \%)\end{array}$ & $\begin{array}{l}16 \\
(29.1 \%)\end{array}$ & $\begin{array}{l}2 \\
(3.6 \%)\end{array}$ & $\begin{array}{l}4 \\
(7.3 \%)\end{array}$ & $\begin{array}{l}13 \\
(23.6 \%)\end{array}$ & 2.53 & 1.591. \\
\hline $\begin{array}{l}\text { There Has Been Marked Growth In } \\
\text { Demand For Transport Services That Has } \\
\text { Improved }\end{array}$ & $\begin{array}{l}25 \\
(45.5 \%)\end{array}$ & $\begin{array}{l}16 \\
(29.1 \%)\end{array}$ & $\begin{array}{l}10 \\
(18.2 \%)\end{array}$ & $\begin{array}{l}3 \\
(5.5 \%)\end{array}$ & $\begin{array}{l}2 \\
(3.6 \%)\end{array}$ & 1.98 & 1.06 \\
\hline
\end{tabular}

The Findings Illustrated In Table 10 On Profitability In The Matatu Transport Industry Indicates That A Mean Of 3.62 And A Standard Deviation Of 1.19 Of The Respondents Agree That They Receive More Money When Affiliated To The Organization While Most Of The Respondents Were Neutral On The Steady Predictable Cash Flow. Most The Respondents Agreed On The Issues Of Economic Factors Affecting The Profitability Need To Borrow Money For Operation, Risk Involved In Transport Business And The Growth Of Demand For Transport Business.

\subsection{Correlation Analysis}

Table 11: Pearson Correlation Analysis

\begin{tabular}{|ll|l|l|l|}
\hline \multicolumn{2}{|c|}{} & Cost Of Capital & Capital Structure & Profit \\
\hline $\begin{array}{llll}\text { Cost Of Capital } \\
\text { Capital Structure }\end{array}$ & Pearson Correlation & 1 & &. \\
Profit & Pearson Correlation & $0.716^{* *}$ & 1 & \\
\hline
\end{tabular}

A Strong Positive Relationship Was Established Between The Dependent Variable (Profitability) And The Two Independent Variables For The PSV Matatu Transport Industry. Table 11 Above Shows That The Correlation Between Profit And Cost Of Capital Was $(\mathrm{R}=0.698, \mathrm{P}<0.01)$, Profit And Capital Structure Had $(\mathrm{R}=0.670, \mathrm{P}<$ 0.01). There Was Also A Strong Relationship Among The Independent Variables $\mathrm{Of} R=0.716, \mathrm{P}<0.01$. This Implies That The Variables Are Inter-Dependent And Their Efficient Management Has A Significant Effect On Profitability. Multicollinearity Test Was Conducted With A Variance Inflation Factor (VIF) Of Less Than 10 (Thomas, 2008). The Finding In Table 11, The VIF Of 6.181 Resulted For Both Independent Variables And Therefore Multicollinearity Did Not Exist. 


\subsection{Regression Analysis}

Table 11: Regression Coefficients

\begin{tabular}{|c|c|c|c|c|c|c|c|c|}
\hline \multirow[b]{2}{*}{ Model } & & \multicolumn{2}{|c|}{$\begin{array}{l}\text { Unstandardized } \\
\text { Coefficients }\end{array}$} & \multirow{2}{*}{$\begin{array}{l}\text { Standardized } \\
\text { Coefficients } \\
\text { Beta } \\
\end{array}$} & \multirow[t]{2}{*}{$\mathrm{T}$} & \multirow[t]{2}{*}{ Sig. } & \multicolumn{2}{|c|}{ Collinearity Statistic } \\
\hline & & $\mathrm{B}$ & Std. Error & & & & Tolerance & VIF \\
\hline \multirow{3}{*}{1} & (Constant) & 0.125 & 0.145 & & 0.864 & 0.001 & & \\
\hline & Cost Of Capital & -0.832 & 0.112 & 0.620 & 0.741 & 0.002 & 0.162 & 6.181 \\
\hline & Capital Structure & 0.912 & 0.084 & 0.913 & 10.869 & 0.000 & 0.162 & 6.181 \\
\hline
\end{tabular}

Regression Results In Table 11 Shows That Cost Of Capital Has A Significant Effects On The Profitability Of The Industry At $(\mathrm{T}=0.864$, P- Value $=0.002)$ With A Coefficient Of -0.832 Indicating That An Increase Of 0.832 Leads To A Decrease Of Profit By 0.832. The Cost Of Equity And Debt Overall For Individual Projects Profoundly Affects The Profitability Of The Investment. Expectations About Profit Determine What Projects Manager Will Invest Or Will Not Invest In But It Also Determines Whether The Company Succeeds Financially (Peavler, 2002). Michael (2004) In Order To Build New Plants, Buy New Equipment, Develop New Products And Upgrade Information Technology Business Should Have Capital. For Every Business Decision The Manager Has To Decide If The Cost Of Capital Is Favorable. It Also Shows That Capital Structure Has A Significant Effect On The Profitability Of Industry At T = 10.869, P- Value 001) With A Coefficient Of 0.912 Indicating That An Increase Of 0.912 Leads To An Increase Of Profitability Of The Industry. The Regression Model Equation Was $\mathrm{Y}=0.125-0.832 \mathrm{X}_{1}+0.912 \mathrm{X}_{2}$ Equation (4)

Table12: Regression Results Model

\begin{tabular}{l|l|l|l|l|l|}
\hline Model & R & R Square & Adjusted R Square & $\begin{array}{l}\text { Std. Error Of The Durbin-Watson } \\
\text { Estimate }\end{array}$ & \\
\hline 1 & $0.970^{\mathrm{a}}$ & 0.941 & 0.938 & 0.371 & 1.028 \\
\hline
\end{tabular}
A. Predictors: (Constant), Capital Structure, Cost Of Capital
b. Dependent Variable: Profit

According To The Findings On The Table 12, Finance Management Practices Attributes To 94.1\% Of The Changes In The Profitability In The Matatu Industry. The Finding Indicated A Durbin- Watson Value Of 1.028.

\section{Conclusions}

This Study Undertook To Seek An In Depth Understanding On The Effect Of Financial Management Practices On The Profitability In Matatu Transport Industry With A Particular Interest In Matatu Organizations. The Conclusion Of The Hypotheses Was That:

A) The Cost Of Capital Had A Significant Effect On Profitability Of PSV Matatu Transport Industry In Kenya At $\quad \mathrm{T}=0.741, \mathrm{P}-$ Value $<0.001$.

B) The Capital Structure Had A Significant Effect On The Profitability Of PSV Matatu Transport Industry In Kenya At $\mathrm{T}=10.869, \mathrm{P}-$ Value $<0.001$

The Study Found Out That Under Cost Of Capital, Most Shareholders And Non Shareholders Have Higher Preference For Owner Contributed Capital Or Equity. Nonetheless, Debt Is Also Used Invariably By The Respondents And Major Elements That Determine Its Use Are The Cost Of Capital And Risk. The Independent Variables Attributes To $94.1 \%$ In The Variation Of Profitability In This Industry Hence The Variables Are Important Components In The Business.

The Study Therefore Makes The Following Recommendations Regarding The Financial Management Practices At The Matatu Transport Industry As Measures That Can Be Undertaken To Improve Profitability.

First, The Organizations Should Make It Possible For Members To Access Loans At Lower Interest Rates By, Entering Into Funding Commitments With The Financial Institutions. It Should Also Have Plans To Access A Wider Pool Of Equity Financing By Listing In The Capital Markets.

The Organization Should Advice The Investors On The Optimal Capital Structure Whose Profitability Is Highest.

The Matatu Transport Industry Is Afflicted By Various Costs Which Erode The Profitability From The Industry Which Should Be Managed 


\section{REFERENCES}

[1] Brigham, E.F; And Ehrhardt, M.C. (2008). Financial Management Theory And Practices; Thomson South Western.

[2] Aduwo, I.G. (1990). The Institutional And Organizational Structure Of Public Road Transport In Kenya. Thesis University Of Nairobi.

[3] Aduwo, G.O. (1994). Urban Transport System. A Case Of The Matatu Mode Of Transport In Nairobi. Thesis University Of Nairobi

[4] Pandey, I.M. (1999). Financial Management, 7th Edition; Vikas Publishing House New Delhi.

[5] Horne, J.V. And Wachowicz J. R (2001). Fundamentals Of Financial Management, Pearson Education Asia.

[6] Pandey, I.M. (2001). Financial Management, 8th Edition; Vikas Publishing House.

[7] Emery, D.R; Finnety J.D. And Stowe,J.D.(2007). Corporate Financial Management, 3rd Edition; Pearson International Edition

[8] Glen, A. (2008). Corporate Financial Management, Prentice Hall Of India, Fourth Edition.

[9] Brigham, E.F. And Daves, P.R. (2004). Intermediate Financial Management, 8th Edition; Thomson South- Western.

[10] Ehrhardt, M. C. (1994). Measuring The Company's Cost Of Capital; Harvard Business School Press.

[11] Taggart, R. (1991). Consistent Valuation And Cost Of Capital, Mason, South Western

[12] Brigham, E.F; (2002). Fundamentals Of Financial Management, 10th Edition; Mason, South Western.

[13] Copeland, T; Weston, J. And Shastri, K. (2005). Financial Theory And Corporate Policy; Pearson Addison Wesley. New Delhi.

[14] Murkowitz H. (1959). Portfolio Selection-Efficient Diversification Of Investment; New York. Wiley.

[15] Fama, E.F And French ,K.R. (1992). The Cross Section Of Expected Returns On Stocks And Bonds; Journal Of Finance. Vol 47 No 3 47-56.

[16] Brown, R. (2009). Analysis Of Investment And Management Of Portfolios; Mason South Western.

[17] Kothari, S. And Shanken, J. (1997) Book -To-Market, Dividend Yield And Expected Market Returns; Journal Of Financial Economies Vol. 44 169-204.

[18] Pettangall, G; Dundaram, S. And Mathrur I, (1995). The Condition Relation Between Beta And Returns; Journal Of Financial And Quantitative Analysis. 30, No,101-115

[19] Jaganathan, R And Wang, Z (1996) The Conditional CAPM And L Cross-Section Of Returns; Journal Of Finance Vol.5 Ino 4 1725.

[20] Grundy, K And Malkiel, B. (1996). Reports Of Beta's Death. Have Been Greatly Exaggerated; Journal Of Portfolio Management. 11, No 3, 9-1733

[21] Reilly F.K. And Wright D. J. (2004). Analysis Of Risk- Adjusted Performance For Global Markets Assets; Journal Of Portfolio Management. 30, No 3, 63-77

[22] Sharpe, W. F. (2007). Investor And Markets: Portfolio Choices, Asset, Prices And Investment Advice; Princeton, NJ: Princeton University Press.

[23] Kothari, C.R. (2006). Research Methodology; Methods And Techniques; India: New Age International Publishers.

[24] Mugenda, O.M And Mugenda A.G.(2003). Research Methods. Quantitative And Qualitative Approaches, Nairobi, Acts Press

[25] Modiglian, F And Miller, M.H. (1958). The Cost Of Capital Corporation Finance Theory Of Investment; American Economic Review. Vol 37 No. 397-406

[26] Gitman, L. J.(2005). Principles Of Management Finance. Pearson Addison Wesley San Diego State University

[27] Michael T.J (2004), Cost Of Capital And Returns. Journal Of Finance. Vol 3, No 4. 67-86

[28] Peavler, R. (2002), Capital, Cost Of Capital And Return On Capital, Journal Of Finance. Vol 1, No 4, $21-\backslash$ 